\title{
ORAL EPICS IN KALAHANDI
}

\section{Mahedra Kumar Mishra}

Kalahandi is a rich treasure of traditional knowledge. Folklore in Kalahandi plays an important role in retaining and regenerating the traditional values and educate the people through its learning process. The folk songs, tales, legends, tribal myths and oral epics, proverbs, riddles, and folk performing arts are current among the different classes of people irrespective of their caste or tribe.

The literacy rate of the district is 34 percent. In fact about 95 percent people live in rural areas and out of them 30 percent belong to tribal communities. Major tribes like the Gonds, Kondhs, Sabars, Bhatars, Banjaras, Parajas, Bhunjias, Binjhals and Paharias are prominent in this district for their distinct ethnic culture. The Gaurs (milkmen), the Keutas (fishermen), the Kumbhars (potters), the Sundhis and the Kalars (liquor seller), the Lohars (blacksmith) are the major castes constituting the peasant society. All these tribes and castes have a common sharing of folklore. In addition to it, the tribal communities have their own folkore in their own languages.

Oral epic is a new area of study in folkloristics. Generally, the narrative poetry attributed to a story found in oral form performed by the professional singers and the ethnic bards accompanied by musical instruments nominated to a particular religious or social occasion is an oral epic. In a high society, the bardic tradition was in existence. The Suta, Charana, Bhata and Magadha were the royal singers representing the glorious history and caste genealogisy of Hindu kings in India.

The royal dynasties from Rajput lineage in Kalahandi were the Naga and the Chauhans. Prior to the Naga and Chauhan rule in ancient Kalahandi and Khariar kingdom respectively, the Gonds, the Kondhs and the Bhunjias were the tribal rulers exercising their administrative power as the ruler of this region. The glorious history of origin of the Naga and Chauhans is found in written form where as the tribal rulers had their own ethnic clan-bards to keep up their caste history and geneologies. For this, the caste-bard or clan-bard was patronised by their clan-master of their main castes/tribes. 
As mentioned earlier, the occupation based castes in the villages and the tribal communities in forest have formed the agriculture society. The Kondh tribe in eastern Kalahandi and the Gonds in western Kalahandi were the real land owners, administrative heads and the religious heads till independence. The structure of village administration and religious function by the Gonds and the Kondhs are still continuing in the tribal villages of Kalahandi despite of the modern panchayati raj system. The village head-man was called Gauntia. The religious head was 'Jhankar' for the Gonds and the 'Jani' for the Kondhs, which is in tact in the present religious practice of the village.

Besides all these, the Gonds and the Kondha have their clan-bard or professional singers. The caste genealogies and the origin myth of these tribes including the local history recited by the caste-bards clearly indicates the predominance of the Gonds and the Kondhs as the traditional administrative head exercising their powers and functions over the society. Besides, these dominant tribal rulers, other tribes and castes have also their caste or clan bards. Those who do not have caste bard, also have the specialists from the society to retain their ethnic history and legends through oral narratives.

The bards have their own clan masters from whom they believe to have originated. They have also sub-divided into various clans according to their own clan master. The bards earn their livelihood by singing epic songs, making handicraft and tattooing. Most of them are nomadic, wondering from one place to an other at least for six to seven months in a year. They have their own land and house away from their clan master's house.

The epic singers of Kalahandi may broadly be categorised under the following heads.

1. Ethnic singer or professional caste-bard.

2. Castes and tribes having no bardic tradition but singing the epic song.

3. Priest group in tribal community - male and female priest.

4. Singers independent to castes and tribes. 


\section{ETHNIC SINGERS OR PROFESSIONAL CASTE BARD}

In Kalahandi the following castes and tribes have ethnic bards as shown in Table 1.

\begin{tabular}{lll} 
Tribe/Caste $\begin{array}{l}\text { Sub-caste/ } \\
\text { Bard }\end{array}$ & $\begin{array}{l}\text { Musical } \\
\text { instru- } \\
\text { ments }\end{array}$ & $\begin{array}{l}\text { Name of the epic songs/ } \\
\text { caste genealogy }\end{array}$ \\
\hline
\end{tabular}

\begin{tabular}{|c|c|c|c|}
\hline $\begin{array}{l}\text { Gond \& } \\
\text { Bhatara }\end{array}$ & Parghania & $\begin{array}{l}\text { Kifri (fiddle), } \\
\text { bana }\end{array}$ & $\begin{array}{l}\text { 'Purja' caste geneology. } \\
\text { Chitalsing Chhatri }\end{array}$ \\
\hline Kondh & Marals & Dhundhunia & $\begin{array}{l}\text { Janamkhena- Creation myth } \\
\text { 'Bhimasidi' - Rain God Bhima }\end{array}$ \\
\hline Nangmati & Boguas & $\begin{array}{l}\text { One String } \\
\text { Musical } \\
\text { Instrument }\end{array}$ & Rajphulia-epic \\
\hline Binjhal & Birthia & $\begin{array}{l}\text { Mandal Jhanj } \\
\text { (cymbal) }\end{array}$ & $\begin{array}{l}\text { Jati Janam-creation myth, } \\
\text { origin of Binjhal festival of epic } \\
\text { song. Bariha king of } \\
\text { Borasambar. }\end{array}$ \\
\hline Banjara & Bhat & Dhap & $\begin{array}{l}\text { Meramma-creation of } \\
\text { Goddesses, Lakha Banjara - } \\
\text { culture Hero Mithu Bhukhia } \\
\text { Sewa Bhaya Banjara god }\end{array}$ \\
\hline $\begin{array}{l}\text { Gaurs } \\
\text { (Milkman, } \\
\text { Cultivators) }\end{array}$ & $\begin{array}{l}\text { Ghogia } \\
\text { jachak }\end{array}$ & $\begin{array}{l}\text { Bramhaveena } \\
\text { Local harp } \\
\text { wind } \\
\text { instrument }\end{array}$ & $\begin{array}{l}\text { kharatmal, Barakhena } \\
\text { Bansgeet Bans. }\end{array}$ \\
\hline $\begin{array}{l}\text { Dom } \\
\text { (Scheduled } \\
\text { Cast) }\end{array}$ & Birthia & Muhuri, Tasha & $\begin{array}{l}\text { Jati janam - How they Dhol } \\
\text { became a musician community. } \\
\text { Madhab King Katha-geet, } \\
\text { Salaban raja Katha-geet }\end{array}$ \\
\hline
\end{tabular}

Table 1. The castes and tribes in Kalahandi that have ethnic bards.

\section{CASTES/TRIBES WITHOUT BARDIC TRADITION, BUT SING EPIC SONGS}

The majority castes like Mali. Teli, Keuts and Kumhars and the tribes like the Bhunjias, Paharias (kamars) and Sabars have no caste-bard. But they have their origin myth, epic songs on their 
culture heroes and ancestors. The singers emerge out from the community itself. They can neither be compared to the caste-bard nor are they patronised by their community for their singing. Anyone who is keen to master the epic songs can be a singer in his own community. It is told that they had their epic singers on clan-bards, but in course of time, the bardic custom was abolished due to the heavy demand of the clan-bard. The Paharias are of the opinion that, as their Clan bard demanded high price/alms for his singing profession, out of disgust, they shot the bard with an arrow, and got rid of him.

Following castes/tribes have no caste-genealogists but singers among their community could retain their ethnic knowledge. The distribution of epic songs recited by the professional singers of the caste itself are mentioned in Table 2.

\section{Caste Tribe Epic songs/culture Hero and Narration on} Supreme Gods

\begin{tabular}{|c|c|c|}
\hline & Bhunjia & $\begin{array}{l}\text { origin of Bhunjia, Kachra Dhurua - a culture } \\
\text { Hero of the Bhunjias }\end{array}$ \\
\hline & Paharia & Bddevtar Khena - origin myth \\
\hline & (kamar) & Gandhu Paradhiya - culture Hero \\
\hline & Sabar & $\begin{array}{l}\text { dance, the song of tattooing, romance epic of } \\
\text { Oriya literature, Sashisena, Jarasabar }\end{array}$ \\
\hline Teli & Bhat- & $\begin{array}{l}\text { caste origin from Lord Siva and Parvati, ritural } \\
\text { song "Marriage of Gods and Goddesses" }\end{array}$ \\
\hline Keut & & $\begin{array}{l}\text { Kaivarta Geeta - Origin of Kaivarta caste from } \\
\text { Brahma and Vishnu }\end{array}$ \\
\hline Kumhar & & $\begin{array}{l}\text { origin myth, epic story of king Chandra - dhawja } \\
\text { Kurala Purana by Poet Deena Krishna Das }\end{array}$ \\
\hline Mali & & origin myth, rituals \\
\hline
\end{tabular}

Table 2. Following castes / tribes have no caste-genealogists but singers among their community could retain their ethnic knowledge. These epic songs are recited by professional singers. 


\section{PRIESTS/PRIESTESS ATTACHED TO CASTE AND TRIBE}

In this category the priests and priestess of different castes and tribes perform the ritual and play the role of sacred singers. They retain the mythical epics of the origin of the Gods and the Goddesses and transmit it only to the persons considered to be the priest nominated by the deities in dreams. The Priests also recite the local legends of the migration of deities or authority of one God and Goddess over the other. Similarly the myths and legends of the ethnic heroes and heroines associated with the Gods and Goddesses are also sung by the priests on different occasions. For instance, in Dasahara or Navanna, the mythical songs are narrated while ritual is instituted purely nominated to Gods and Goddesses. But during the worship of the ancestors, (the "Duma") - the priest narrates the glorious deeds and heritage of the "Duma" which is exclusively for ancestor worship. The "Jhankar" and the "Dihari" are the priest

\begin{tabular}{|c|c|c|c|c|}
\hline Tribe & Priest & Shaman & $\begin{array}{l}\text { Myths and } \\
\text { Sacred Epics }\end{array}$ & Function \\
\hline Gond & Jhankar & Dihari & $\begin{array}{l}\text { Budharaja, } \\
\text { Lingadeo, } \\
\text { Jungadeo }\end{array}$ & ancestor worship \\
\hline \multirow[t]{3}{*}{ Kondh } & 1.Govajani & Dishari & $\begin{array}{l}\text { Janamkhena } \\
\text { Puran }\end{array}$ & \multirow{3}{*}{$\begin{array}{l}\text { good harvest, } \\
\text { ancestor } \\
\text { worship } \\
\text { appeases the } \\
\text { earth-mother }\end{array}$} \\
\hline & 2.Khutjani & & $\begin{array}{l}\text { caste origin } \\
\text { settlement }\end{array}$ & \\
\hline & 3.Jogjani & & buffalo sacrifice & \\
\hline Kondh & Gurumai & Gurumai & Bhimasidi & marriage of rain \\
\hline Bhunjia & Female & Female & Bhimabiha & God Bhima \\
\hline Parja & $\begin{array}{l}\text { Priest } \\
\text { Ghogein }\end{array}$ & Shaman & & a 7-days ritual \\
\hline Bhunjia & Jankar & Dihari & $\begin{array}{l}\text { origin of Goddess } \\
\text { and origin of } \\
\text { Bhunjia } \\
\text { Kachradhurua }\end{array}$ & $\begin{array}{l}\text { annual ritual } \\
\text { and ancestor } \\
\text { worship }\end{array}$ \\
\hline
\end{tabular}

Table 3. The status and functions of priests. 
and the shaman respectively in Gond community. The kondh priest and shaman are called "jani" and "Dishari" respectively. While the Dihari or Dishari - the shaman. represent the Gods, Goddesses or Duma, the priest mediates the Supernatural with the human being. He communicates the conversation between spirit and man. The first progenitor is mythologized whereas the Duma of recent past are all ancestor spirits and culture heroes.

The epic songs are considered sacred and have certain roles and functions to awake the caste/tribe with his glorious heritage. The status and functions of the Priests are in Table 3.

\section{SINGERS INDEPENDENT TO CASTES AND TRIBES}

There are some singer communities independent of any castes and tribes. They are known as Devgunia and Basudevia brahmins found in Kalahandi adjoining Gariabandh district of Madhya Pradesh. The Devgunias are the professional singer community depending on people for their livelihood. They move from door to door singing the glory of Goddess Laxmi, selling the paddy craft and get alms from the people. Especially in the month of Margasira (Dec. to Jan.) they move around the villages. They are a local non-tribal caste.

The women folk purchase the images of Goddess Laxmi, Elephant, Lord Jagannath, Lord Balabhadra, and Goddess Subhadra and Lord Gandesh made of paddy and they put them in worship place and worship them throughout the year. They also hear the epic mythology of Goddess Laxmi and offer alms to the Devgunias. Sometimes the villagers arrange the Purana performance programme especially in the month of Margasira. Besides, the Devgunias are the scribes in palm leaf manuscripts and are popular as Natguru (Drama Director) in rural areas. They write drama on the Ramayana and the Mahabharata episodes and organise folk drama.

The Basudevia Brahmins are also a local caste. Their ethnic origin is not known, if they are of tribal origin.

However, their culture, customs, and status is no better than a local tribal Gond. Like the Parghania-bard of the Gonds, they use Kikri and they sing the Ramayana in local version. 


Singer Epics $\quad \begin{aligned} & \text { Musical Function } \\ & \text { instrument }\end{aligned}$

Professional

Debgunia or Laxmi Purana Brahm av worship of goddess Debguru Legendary Epics harp (Male) Folktales Lazmi; prepare daddy craft; public perform ance; folk drama; prepare palmleaf manuscrip (notes); sing legendary epic on local heroes

Basudevia Ramayana, Brahmins Mahabharat in (Male) local version
Kikri fiddle recite sacred narrative invoke mythical epics; sing legendary epic stories; folk tales on culture heroes (prose verse)

\section{Occasional}

Geet Kudia love song, folk (Male) tale

Geet love song, folk Ramkathi Kudien tales (Female) dance; sing; compose songs in performance context

compose song in performance context; tell folk tales, invoke narrative songs

Table 4. The Harijans village singers.

The Geet Kudias (male singer) and the Geet Kudien (female singer) are the talented singers popular for their spontaneous recitation of songs in performance context, especially when a dance competition or song competitions between Dhangra and Dhangri - young boys and girls - are organised in a village. They also sing the epic songs, though they are not professional, but their creative minds have the storage of local legends, epic songs, riddles, songs and myths etc.

Besides, the village Harijans living with the tribal communities have a major stock of knowledge on the tribal language and culture. See more in Table 4. 


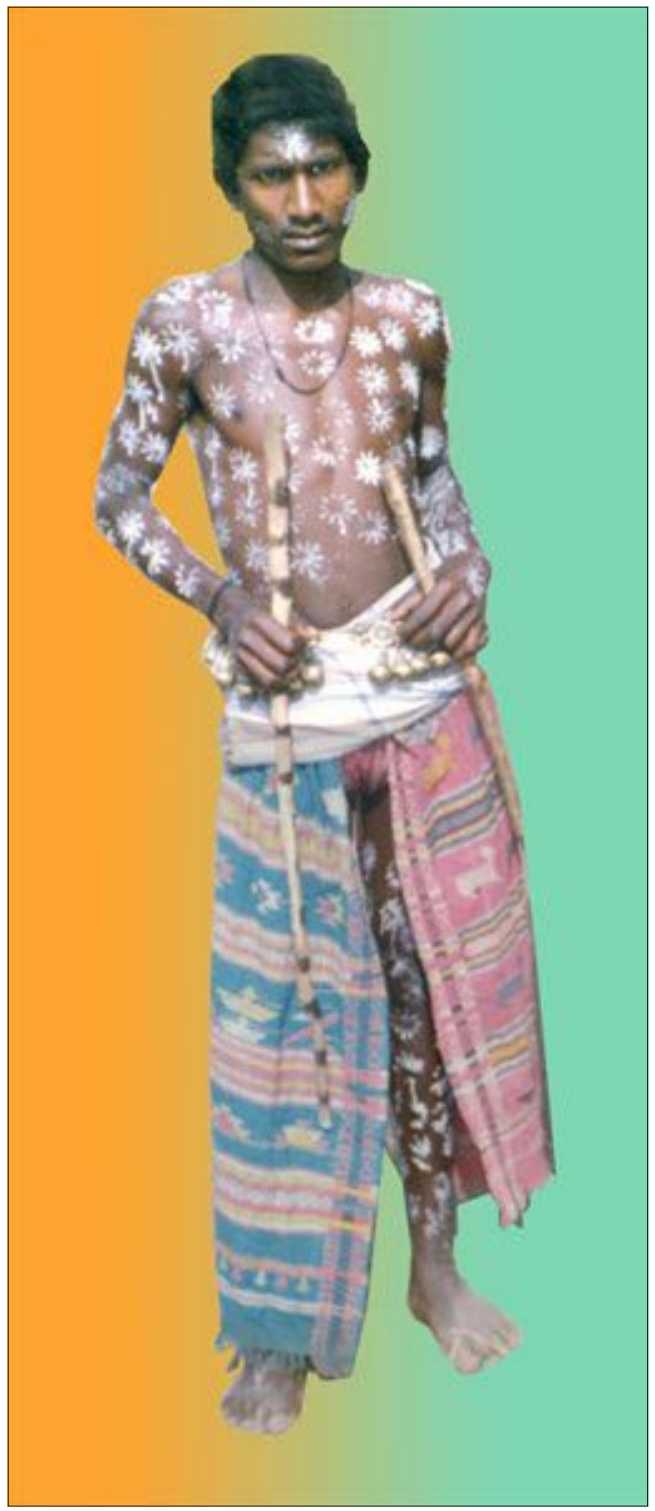

Photo 1. Kharatmal is a Gaur Hero in the traditional dress of a warrior. 
The epic songs in different performance context are of various kinds. These can broadly be divided into sacred narratives and secular narratives.

\section{SACRED NARRATIVES}

The sacred narratives have a fixed place, time and certain rules of performance conducted by the priest for a certain religious and ritualistic purpose. In rites and rituals, fairs and festivals, during the invocation of Duma - the ancestral spirit, the Jani or Gurumai recite the song to glorify the heritage of the Gods, Goddesses and the ancestor spirits. These narrations are believed to be true. During the rituals or festivals, when the narratives are recited, the sacred narratives have the indications on the rules of performing the ritual systematically.

The contents of the sacred narratives are mainly based on the origin of the universe, origin of Earth and nature, evolution of animal and human being, procreation of mankind, struggle for survival, family and social bond, kinship, migration and settlement, ethnic occupation, origin of Gods and Goddesses of each ethnic group, clanwise distribution of land and jungle, distribution of Gods and Goddesses by the clans, history of fight against other tribes for land and jungle, settlement of villages, sharing of land with their supporter caste-group, dissemination of caste/tribe to other areas, invention of farming technology, invention of iron instruments, cultivation of paddy and pulses, village administration and religious organisation, friendship and hostility with other ethnic groups, worship to the Gods and Goddesses for their own victory and security etc. worship of the first progenitor, first priest and the first ancesters - Duma are the major areas of descriptions.

The Parghanias - Gond bard recite the caste geneaology "PURJA" which is a long sacred narrative. The Gond priest 'Jhankar' recite the invocation song on Chaturbhuj Budhadeo, Lingadeo and Janghadeo representing the ancient glory of the Gond gods and heroes.

The Bogua and the Marals - two distinct ethnic bard of the Kondhs recite Janamkhena - creation of the Kondhs, and Bhimasidi - the ladder of Bhima. Bhima is the rain god and culture hero of the Kondhs. 


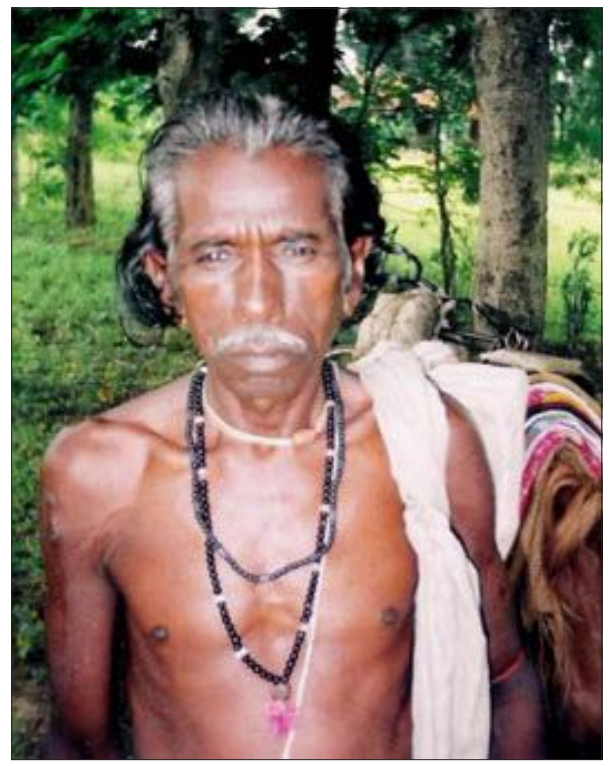

Photo 2. Bansidhar Bisi is a parghania (griot) - singer of Gond epic.

Similarly, the Birthia for Binjhal tribe and the Birthia for the Doms recite the Jati Janam and Purthi Janam during the Dasahara festival and the community rituals. The Kamars recite Baddevtar Khena as their creation myth.

The Ghogia (or Gorgia) for Gaur caste sing Barakhena Bansgeet representing their clan Gods and Goddesses. The narratives were recited during their post harvest festivals and during marriage ceremonies. The Gurumai and the Ghogien in Gond, Kondh and Bhunjia community invoke the 'Duma utra song' - which is the family history or caste geneaologies of the respective tribes. Bhima Biha is another ritual found among these tribes performed where the scarcity of rain or by these tribes drought occurs in Kalahandi. People organise a marriage ceremony of the Rain God Bhima with a young girl of the tribe named Kondhen and the ritual marriage, it is believed, causes ample rain for their harvest. 
The sacred narratives are thus known as Janam Khand Puran, Bad Devtar Khena, Janam Khena, Jati Janam and Purthi Janam, Purja, Bhima Sidi and Bhima Biha etc. All these narrative poetry is commonly termed as Geet, Puran or Khena, Janam Khand and also Jati Puran. The fisher folk (Keuta) community, call it Geeta. The content of the sacred narrative varies from tribe to tribe, depending on their socio-economic status. The Gonds is narrated. It is their Purja in which the history of the Raj Gonds have clearly indicated as they were the land owner and administrative heads. The Kondhs have already adopted cultivation as their major occupation. In their 'Pod puja' - buffalo sacrifice festival the main Priest (Govajani) worship Dharnimata - Earth Mother, Goddess Laxmi and Goddess Durga. He offers milk to laxmi and sacrifice buffalo for Goddess Durga again influenced by sapta Sati Chandi mythology.

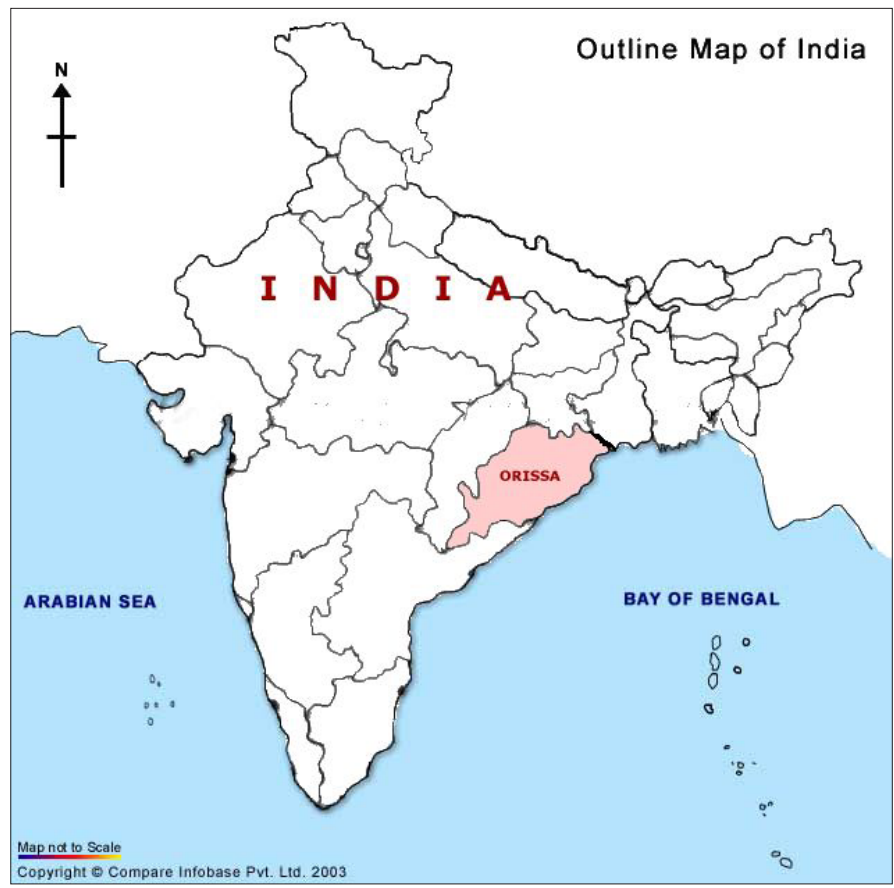

Map 1. Outline Map of India. 


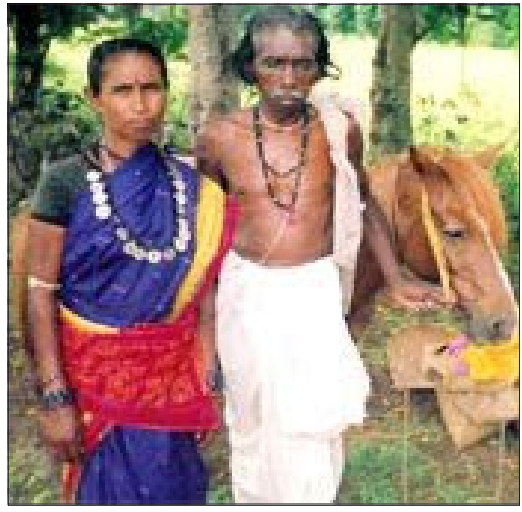

Photo 3. Bansidhar Bisi with his wife, and their horse. A fiddle is hanging on his shoulder.
The buffalo sacrifice ritual of the Kondh tribe reflects the origin, migration, settlement, transition from food gatherer to food producer technologies and ultimately the land owner and local administrator of their 'chak' - habitat. The Kamars - a minority tribe in their Bad Devtar Khena - a long narrative song, invoke their supreme God to help them in hunting and collecting forest products and pray for the in tact jungle without external attack by any other community. It has been so as they still live on forest products and hunting.

The main functions of the sacred narratives are to ensure security of the community such as to get ample harvest, to gain all worldly objects, to keep the habitat free from diseases and external fear, to keep the jungle evergreen and to get food and rain for their sustenance. They appease their ancestor spirits and the supreme Gods for all these objects. They believe that if their ancestor spirits are not satisfied with their actions, they will curse them. So they promise to their Gods and ancestors that they are righteous and have not violated the morals and ethics inherited from their ancestors. Their possibility of gaining the worldly objects as stated above are symbolically expressed in the ritual performance and the success or failure is ensured and accordingly they establish their confidence with their past and regulate the present.

\section{SECULAR EPICS OR EPICS OF CULTURE HEROES}

The narrative songs which have the flexibility of performance in any audience irrespective of caste, sex and age may be termed as secular epics. Though these are emerged out of the sacred narratives with a strong ethnic background, these are less religious and more legendary. It is called Akhyana - commonly termed as 'Khena' 
or 'Geet' or 'Khatha' in the society. These epic stories are believed to be true which represent their ethnic heroes of recent past attached to a place, and time and events.

The professional epic singers of aforesaid categories have a major stock of such Geet and Katha related to their culture heroes and legendary heroes with an ethno-historical background.

Each ethnic group has its own epic narrative resting on their cultural context. The Gond tribe of Kalahandi have the representative epic songs like Chittal Singh Chhatri, Lohagundi Raja, Kadel Kachhar Katha and Kachra Dhurua Geet etc. As the Gonds of Kalahandi have a rich cultural heritage associated with the Gonds of Central India, they have a number of local heroic legends sung by the Praghanias.

The Boguas and the Marals are Kondh bards singing the narratives like Madhab King Katha, Nangmati Rajaphulia and Mara deo Raja Katha. Nangmati Rajaphulia is a tragic epic song recited by the Boguas in which the heroine had to commit suicide when she found that the hero she chosen as her husband was incidentally no one except her own brother. Maradeo Raja Katha is the secularised form of the mythic song of the Kondhs. The Banjaras have their clan bard. They sing the epic songs Lakha Banjara, Sobhanaik Banjara which represents their ethnic occupation as well as the heroic actions of the Banjara culture heroes. The Kamars or the Paharias have a number of epic narratives. Gandhu Paradhiya, Koko Bhaini. Luhagundi Raja, Kamul surua raja are some of the popular epic songs representing their ethnic culture. Similarly the Binjhals have also epic song, like the Karma song and the narrate poetry. The Bhunjias have their Allah Uddal and Khalnia Veer Katha depicting Bhunjia culture. Each narrative is nominated to the main dramatic personae of the epic. The Gaur epic songs have been named according to the name of the hero and the heroine. There are twelve Khena or twelve episodes. Each episode represents the story of a hero and the heroine e.g.

i) Rupdhar - Hirandri Khena

ii) Sunadhar - Ramela Khena

iii) Kotrabina - Ramela Khena

iv) Hadukurria - Nilendri Khena etc. 


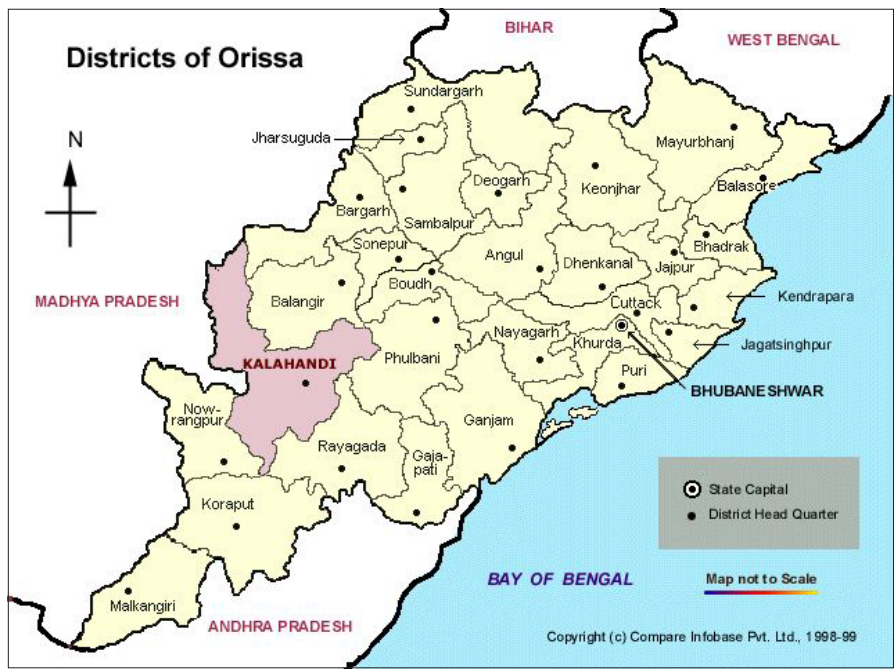

Map 2. Districts of Orisssa.

The content of the secular epic songs narrates the themes of love, war, victory, gaining or regaining of kingdom, supremacy over other tribes. The content and motifs of these epics have striking resemblance with that of the metrical romance of Europe. The epic story have imaginary elements with fantasy representing the demi Gods and Goddesses of the spiritual world of the traditional culture. Magic, witch craft and sorcery are the elements help the hero and the villians in becoming powerful men. The supernatural power helps the hero and the heroine in wining the race. In ethnic based epics, innovations in agriculture and inventing equipments for the agricultural work, getting water (from Indra and the demigod Bhima (rain God) for the field, yielding a bumper harvest are some of the key motifs to be an ideal hero. The distinctive occupation and the custom of the tribes are chartered in their epics. In most of the heroic epics the hero is neglected by the elderly parents resulting his absentation. On the way he faces many obstacles and overcomes them with the supernatural help from the saints, friends, Gods and Goddesses. Frame repetitions are recurrent in such epics and ultimately the hero wins the race punishing or killing the villians/enemies. He is also rewarded with regaining his power, as well as marrying beautiful girls. 


\section{VISUAL EPIC OR DRUSY KAVYA}

Interestingly, some of the local epic-story found among the tribes have been found in drama form, which indicates the multi-generic form of folk epics. The Kondh-Paraja tribes and the Dom caste perform the epic drama called "desianat" which means regional nata. Desia is a link language in Kalahandi and Koraput district used by more than 51 tribes and other non-tribals. This epic story performed in drama form reminds us of the kavya-natya form and the chhandanatya form, as the dialogues in desianat are in verse form composed by the local folk dramatists.

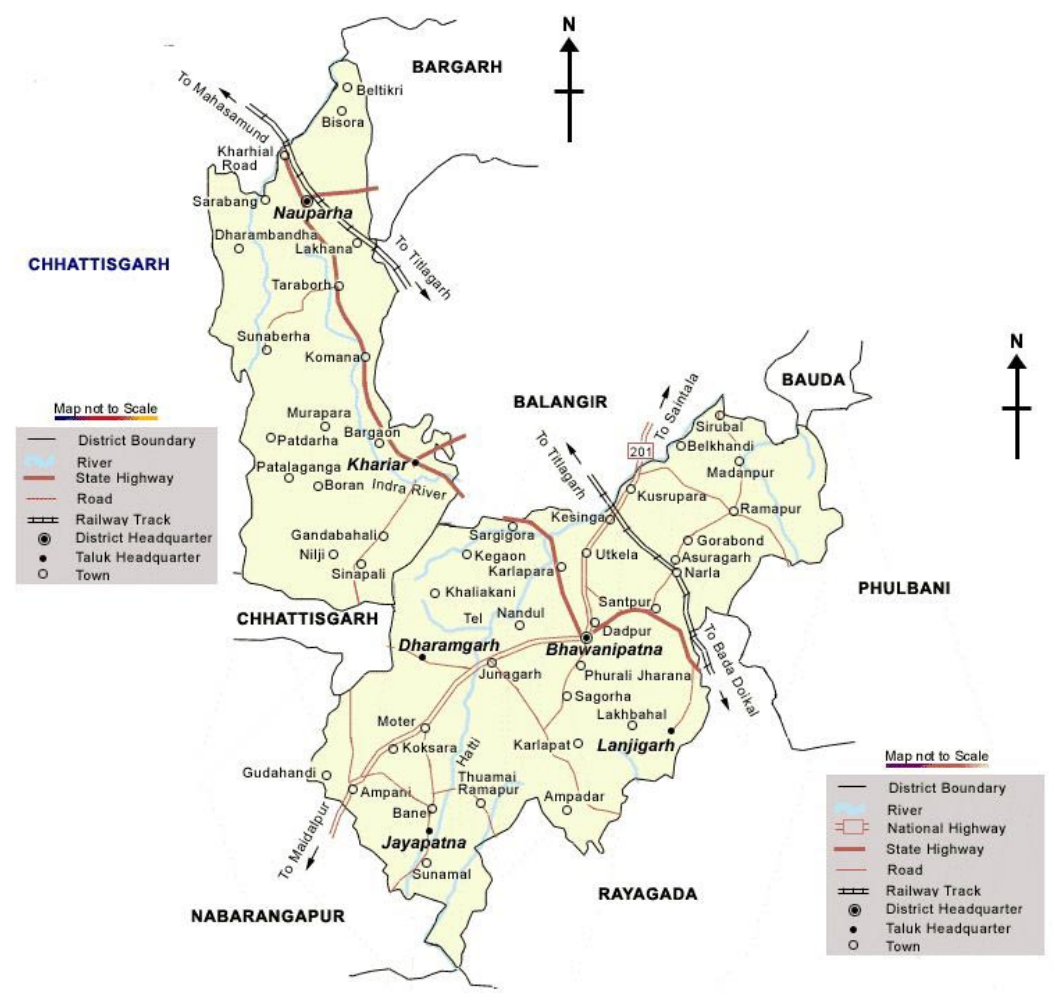

Map 3. Map of Kalahandi. 
Sometime, the professional singers compose such epic drama. While the sacred narratives have religious functions, the secular narratives have socio-cultural functions. It is related to their legendary heroes of recent past vivid in their memory. Through the chronological arrangements of various events of their culture heroes they try to relate their caste history and genealogies with some place and time. Thus the characters of these narratives are semitrue and semi-imaginary. It is found that even in the secular epic the replica of the mythic character of the great epics of the country are clearly discernible. However, the ethnic epics represent the racial memory and ethnic identity of the tribes, though they are secular in nature. It helps in promoting their group consciousness and ethnic solidarity.

\section{TRANSMISSION OF THE ORAL EPICS}

The sacred narratives are transmitted from one generation to the other by professional ethnic singers. The parghanias recite 'Purja' or caste genealogies of the Gonds which is considered secret and not transmitted to others except the family members i. e. to male persons only in the context of ritual performance. Similarly the Govajani - priest singer of the Kondhs sing the "govautra geet" only in the ritual place of goddess Dharnimata during buffalo sacrifice festival (pod puja). The recitation starts in the evening and it continues through the whole night till next morning. The new singers assist the govajani and the learning of the narrative is achieved by rote memory. Similarly the Boguas and the Marals - the Kond bards also transmit their oral epic song to their family members only. The clan bard, priest and the gurumai are restricted to recite the song without a ritual fixed for them. Some rituals take place once every twelve years e.g. pod puja or Buffalo sacrifice of the Kondhs. In this case the govajani fails to present the narrative in order and the elderly persons from the community help him in rearranging the events in the text.

The epic songs nominated to culture heroes and legendary heroes (which are open to all) are sung by the singers. There is no fixed time and place for it, but most of the performances take place at night. 
Each main singer has three to four young singers accompanied by musical instruments. The junior singers use to master the narratives by repeating the mainline of the main singer which also help the audience to comprehend the narrative. The sacred epics are performed in this manner. But the heroic epic songs are recited by the singer without repetitions. But to remember the lines the singer uses nonsense syllables till he gets it in his memory. Further his refrain helps him in taking a pause to jump from one event to the other. Whereas the method of transmission of sacred narratives is vertical within the family and clan group, it is linear in respect of secular epics.

\section{EPIC COMPOSITION}

Each ethnic group has its own epic cycle. It consists of two cycle, five cycles and twelve cycles. Each cycle is known as khena, khand, katha or geet. The local meaning of 'khena' means the branch of a tree. Most possibly the nomenclature might have been derived from the Sanskrit word Akhyana. 'khand' means a part of the whole purana or epic cycle. In sanskrit, epics like Koshala Khand, and Utkala Khanda are available. Similarly the Bhimasidi sung by the Priests and Gurumai are 1. Janamkhand Puran and 2. Nanagar Khand Puran. In first part the birth of the hero and in second part his heroic deeds are described. 'katha' 'geet' mean tales and songs. The epic song represents a tale performed in the narrative poetry form. So the katha and geet attributed to the epic is justified. The most important aspect of epic study is textualising the epic performance into epic in the mental text of the poet and its verbal expression is most important aspect in studying the texture and the nature of composition. The singers are not literates, so their epic songs are always found in oral form. Hence their epic composition is based on their epic performance. The nature of composition varies from one performance to the other due to the performance context such as time, mood of the singer and audience's response. However, the content of the epics are revealed through some culture specific language and phrases which are highly proverbial in nature, it is found that the epic composition has some stock language and metaphorical phrases, which helps the traditional singer to express the texts in a given frame work. Therefore, the language 
of the epic text is different from the day to day spoken language of the same singer or audience. It has a literary and cultural flavour. However, the structure of the epic remains intact, which means without breaking the story they compose the epics.

In course of the performance it is found that the epic narratives are ingrained with mulitgenres of folklore. They are proverbs, folk metaphors, images, similies, phrases, songs, lullabies, lamentation and so on to make the epics lively. The arrangements of episodes in the mental text of the singer are expressed through the poetic folk language and cultural symbols. Each episode in an oral epic or a myth is like a tree with various branches (khena). The singer has to link up each khena with the other and arrange the episodes in such a manner that the events will have a logical sequence leading to the total epic text in a systematic order, so that the epic tree is complete with all the khenas.

During epic performance, if the singer fails to correlate one episode with that of the other and distorts the text, the elderly persons from the audience guide him. They ask the singer, "You must water the plants, in such a manner that it must saturate from the starting point to the ending point without breaking its flow. According to them the epic is like a tree and the singer is a gardener. He must know how to nourish the epic tree to make it green with leaves bearing the fragrance of flower resulting fruits.

Most of the epics, caste genealogies are long narrative. Each epic take nights together to complete the total cycle. Even the Bhimasidi is recited for seven nights. Barakhena Bansgeet for twelve nights. It is learnt by the youngers by the process of rote memory while performing them repeat the mainline sung by the singer. This is the essence of the song. So it is called gova. Till the second line is uttered by the main singer, the youngers use to repeat the first line. The age old proverbs, sayings, and experience form the essence of the song which is related to customs, rituals and tradition.

\section{TRANSITION IN EPIC NARRATIVE}

Due to the influence of puranic tradition the bards infused the mythic characters and events identical to the ethnic epics. When the epi- 
sodes or events or characters of puranas are found similar to the ethnic hero of their traditional epics the particular episode is regenerated forming a new composition in the mental text of the bard. The assimilation of ethnic culture and puranic culture gives a new force to the epic singers as well as the ethnic group to extend their glorious heritage with the puranic tradition of India. For instance, the debgunias claim their ancestry from Devaguru Vrihaspati and the Basudevia Brahmins from the Brahmins of Gaya of Ramayana age. The parghanias are said to have their origin from Lord Shiva or Mahadev. The fisher folk (keut) associate themselves with sage Parasara and the kumbhar (potter) community with the Pandavas after Draupadi Swayamvara etc. Through this process the local epic heroes have been characterised as the puranic epic hero and vice versa.

\section{GENDER ISSUE}

In all the epics, women have been portrayed as the supreme power. The sacred epics/myths/narratives and invocations are nominated to the goddesses. Earth mother goddess is the supreme goddess of the tribal communities. In Baddevtar Khena and in Govantara myth, the Earth mother goddess has been described as goddess Durga, also goddess Laxmi.

In heroic epics like Chittal Singh Chhatri and Nangmati Rajaphlia, role of women is not prominent in comparison to the males. However, the heroines have played a supporting and inspiring role in making the hero victorious.

\section{Comments}

Parghania: Gond bards in Madhya Pradesh and Maharastra are called Pradhans where as in Orissa they are known as Parghania. Each Gond clan had been assigned to a cluster of villages identified as Parghana. The clan bard assigned to the Gond clan in a particular Parghana is a Parghania. Each parghania considers his Kikri as his Varna - caste symbol.

Boguas and Marals: The Boguas and the Marals are Kondh bards. They are minority sub-tribe of the Kondhs. Both of them play Dhundhunia - a one stringed musical instrument. 
Gogia or Ghogia: Clan bard of the Kondhs/the Gond castes. They use Brahma Veena - a local harp.

Jachak: Those who have come to give something. Here the bards give ethnic knowledge to their main caste.

Birthia: The bards who sing the heroic songs, Bir means warrior, the man who sings the glory of the Birs are Birthia.

Govajani: 'Gova' means essence and 'Jani' means Kondh priest. The essence of the sacred myth is always recited by the Govajani. The co-singers of Govajani use Sadki - a wooden musical instrument with twinkling bell played in both the hands to keep the rhythm of the narrative.

Devgunia: A man who praises the valour of the Gods and Goddesses. Deva Guna means the valour of the Gods and Devgunia means the singer of it. They use Brahmaveena and especially dedicated for Goddess laxmi. They show their ancestry from Devaguru Vrihaspati.

Basudevia Brahmin: A minority nomadic caste found in Gariabandh district of Madhya Pradesh adjacent to Kalahandi district of Orissa.

\section{References}

Kuanr, Durga Charan 1980. Orissa District Gazatteers. Kalahandi Bhubaneswar.

Thaper, Romila 1978. The Ancient Indian Social History. New Delhi: Orient Longman.

Singh Deo, J. P. 1987. Cultural Profile of South Kosala. New Delhi: Gian Publishing. 